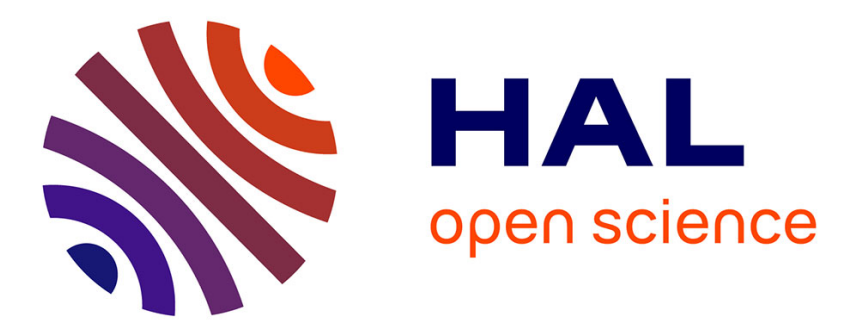

\title{
Assessing pesticide pollution risk: from field to watershed
}

\author{
M. Houdart, P. Tixier, A. Lassoudière, F. Saudubray
}

\section{To cite this version:}

M. Houdart, P. Tixier, A. Lassoudière, F. Saudubray. Assessing pesticide pollution risk: from field to watershed. Agronomy for Sustainable Development, 2009, 29 (2), p. 321 - p. 327. 10.1051/agro:2008042 . hal-00455358

\section{HAL Id: hal-00455358 https://hal.science/hal-00455358}

Submitted on 10 Feb 2010

HAL is a multi-disciplinary open access archive for the deposit and dissemination of scientific research documents, whether they are published or not. The documents may come from teaching and research institutions in France or abroad, or from public or private research centers.
L'archive ouverte pluridisciplinaire HAL, est destinée au dépôt et à la diffusion de documents scientifiques de niveau recherche, publiés ou non, émanant des établissements d'enseignement et de recherche français ou étrangers, des laboratoires publics ou privés. 


\title{
Research article
}

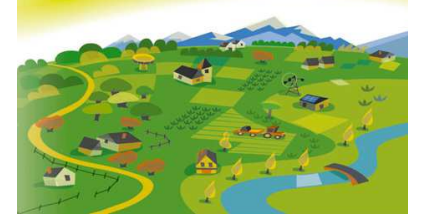

\section{Assessing pesticide pollution risk: from field to watershed}

\author{
Marie HoudART $^{1,4 *}$, Philippe TIXIER ${ }^{1}$, André LASSOUdiÈRE $^{2}$, Frédéric SAUdUBRAY $^{3}$ \\ ${ }^{1}$ CIRAD, UPR 26, PRAM, BP 214, 97285 Lamentin Cedex 2, Martinique, French West Indies, France \\ ${ }^{2}$ CIRAD, UPR 26, avenue Agropolis, 34398 Montpellier Cedex 5, France \\ ${ }^{3}$ Cemagref, Unité ADER, 50 avenue de Verdun, Gazinet, 33612 Cestas Cedex, France \\ ${ }^{4}$ Cemagref, UMR METAFORT, 24 avenue des Landais, BP 500085, 63172 Aubière Cedex, France
}

(Accepted 30 June 2008)

\begin{abstract}
Pesticides used for intensive agricultural production threaten the water resources of the French West Indies. For example, the pesticide chlordecone was used until the nineties in banana fields. Operational and simple tools are needed to assess the potential risk of pollution by pesticides. Here, we propose a method to assess the spatial variability of pollution risk on a watershed scale. This method proceeds in four steps: (1) surveying practices; (2) determining the pesticide load for each field in the watershed; (3) establishing an indicator of pollution contribution for each field based on the load of pesticide per year weighted by the toxicity and solubility of each molecule; and (4) spatializing the indicator. We applied this method to an agricultural watershed in the north of Martinique, French West Indies. The results showed detailed information of pesticide dose spread and the distribution of the pollution risk, highlighting risk areas. Specifically designed for the volcanic and tropical areas of the French West Indies, our method could be adapted by integrating other data on soil-climate conditions and the topography.
\end{abstract}

pollution risk evaluation / pesticides / agricultural practices / Martinique / indicator / GIS / spatial analysis / chlordecone

\section{INTRODUCTION}

Agronomists use information from different agricultural, economic, ecological or social sources to address issues on different scales (Dumanski et al., 1998; Marceau, 1999; Dalgaard et al., 2003). In the specific case of water pollution by pesticides, there is a major issue concerning the scales on which data are acquired and the evaluation is performed. For instance, acquisition is often performed on the plot scale, where the farmer's practices take place, but the vulnerability of natural resources must be determined for the watershed. There is thus an up-scaling issue from the plot or the farm scale to the regional or national scale.

Tools like geographic information systems (GIS) integrate in a single database data from different sources and different spatial scales (Dumanski et al., 1998; Marceau, 1999; Bock et al., 2005). They can include thematic maps to spatially represent complex information on practices. For this, indicators are useful because they allow one to take into account several phenomena in a single variable, e.g. practices and their potential impact on the environment (Van Der Werf and Zimmer, 1998; Bockstaller, 2004). Linking pesticide practice indicators with a GIS creates a path between different scales (Aspinall and Pearson, 2000; Stein et al., 2001). Different assessment methods based on agri-environmental indicators have been developed as tools to improve the assessment, management and design of new practices (Smith and McDonald, 1998; Lefroy and Rydberg, 2003). These tools can be implemented by various stakeholders, i.e. farmers, scientists, and agricultural and political coordinators, to assess cropping or production systems at a field, farm or regional level (Halberg et al., 2005; Payraudeau and van der Werf, 2005). The simplest indicators are based on a single variable. Other more complex indicators aggregate several variables measured in the field (Bockstaller et al., 1997; Smith et al., 2000; Van der Werf and Petit, 2002) and/or outputs of models (Guipponi, 1998). Concerning the risk linked with pesticide use, several types of indicators are available (Sánchez-Bayo et al., 2002). Some consist of a simple calculation, like the amount of active ingredient or the number of treatments, some are expressed as scores resulting from the aggregation of variables linked with the fate of the active ingredient and toxicological variables, and others are based on a risk ratio approach that compares a predicted concentration in the environment through a model and an ecotoxicological concentration (Levitan et al., 1995; Reus et al., 2002).

\footnotetext{
* Corresponding author: marie.houdart@ cemagref.fr
} 
In the French West Indies, indicators should be developed to assess the risks of surface water pollution and to represent their spatial pattern. Indeed, the existing tools for the assessment of pesticide pollution risk developed for temperate contexts are usually not suitable in the tropical context. The most remarkable differences between temperate and tropical contexts are that agricultural practices are not synchronized by a winter season and that the soil-climate conditions are specific, e.g. volcanic soils and warm-humid climate.

Also, the existing indicators are often unsuitable for evaluating the pesticide practices on a large scale where agricultures are diverse (Devillers et al., 2005). Tropical dynamics are such that the pesticide programs vary rapidly from one place to another within the same watershed: there is no winter and tropical cultures change rapidly, e.g. three months with roots, a few months with vegetables (Kimura et al., 1998; Panke and Quimby, 2000). Agronomists' and policymakers' demand for tools to assess water pollution risk is all the greater as standard water transfer models are not able to take into account the complex volcanic environment of the islands, as in Martinique. Existing indicators such as the Rpest indicator (Tixier et al., 2007) require a large amount of data and need to be linked to a simulation model; they are thus for researchers and not for policymakers. Furthermore, Rpest concerns only bananas. More generally, existing models used to assess nonpoint source pollution often require a large amount of data for their calibration (Corwin et al., 1997). The problem is that there is a lack of knowledge on pesticides in tropical areas.

In this article, we present a method to easily assess the potential risks of pesticide pollution on a watershed scale in the context of tropical areas with a high diversity of cultures, and without information on the fate of pesticides in the environment. This method is based on the formalization of pesticide practices on a plot scale in order to acquire a simple dataset that can be spatialized. This method was tested in Martinique (French West Indies), where the problem of water pollution by pesticides is a major environmental issue. In Martinique, stakeholders need operational tools to prevent pollution, e.g. by chlordecone, which was used until the nineties in banana fields, and is today a major long-term source of pollution of soil and water resources.

\section{MATERIALS AND METHODS}

\subsection{Study area description}

Our study took place on the flanks of the 'Montagne Pelée' volcano, in the north of Martinique (French West Indies); $14^{\circ}$ 49' $06^{\prime \prime} \mathrm{N}, 61^{\circ} 06^{\prime} 33^{\prime \prime} \mathrm{W}$ (Fig. 1). The 1210 hectares of the Capot river watershed include six sub-watersheds characterized by great agricultural diversity: banana for export, pineapple, meadows, fruit trees, roots and vegetables (Fig. 2). This area includes $30 \%$ of the potable water springs of the island (about 400000 inhabitants in 2007). This water resource is often polluted by pesticides; between 1999 and 2002, 23 active ingredients were detected. Among these, nine exceeded the concentrations allowed by regulations.

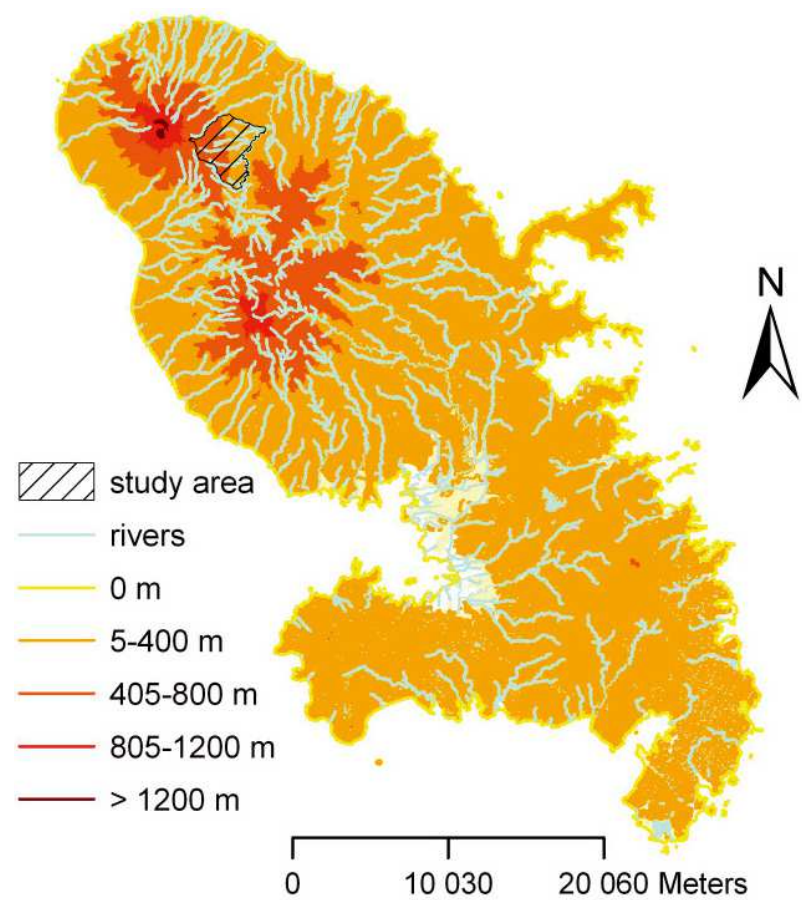

Figure 1. Localization of the study area on the island of Martinique (French West Indies).

According to a detailed survey of the soils of the French West Indies (Colmet-Daage and Lagache, 1965), the soil type of the watershed on the Capot river is an Umbric Andosol in the higher elevations and a Nitisol in the lower altitudes (FAO, 1990). On a similar watershed in Guadeloupe, French West Indies, Cattan et al. (2006) showed that, for banana plantations, runoff is generally moderate on this type of soil, with mean runoff coefficients of 5 to $11 \%$, and always less than $34 \%$, for a given rainfall event. However, Cattan et al. (2006) explained that this degree of runoff is sufficient to cause significant water contamination due to its flow intensity and to the solubility of the pesticides applied on the soil surface.

\subsection{Methods}

To provide an easy assessment of the pesticides and their risk for the environment on a watershed scale, we proceeded in four steps:

- Surveying pesticide practices all over the watershed

- Determining the pesticide load for each field

- Calculating an indicator of pollution contribution for each field (IcPhyto)

- Spatializing the IcPhyto indicator.

\subsubsection{Survey of pesticide application practices}

We carried out an exhaustive survey between August 2001 and July 2002 on 46 farmers and 468 fields to identify the pesticide application practices. The farmers reported the quantity, 


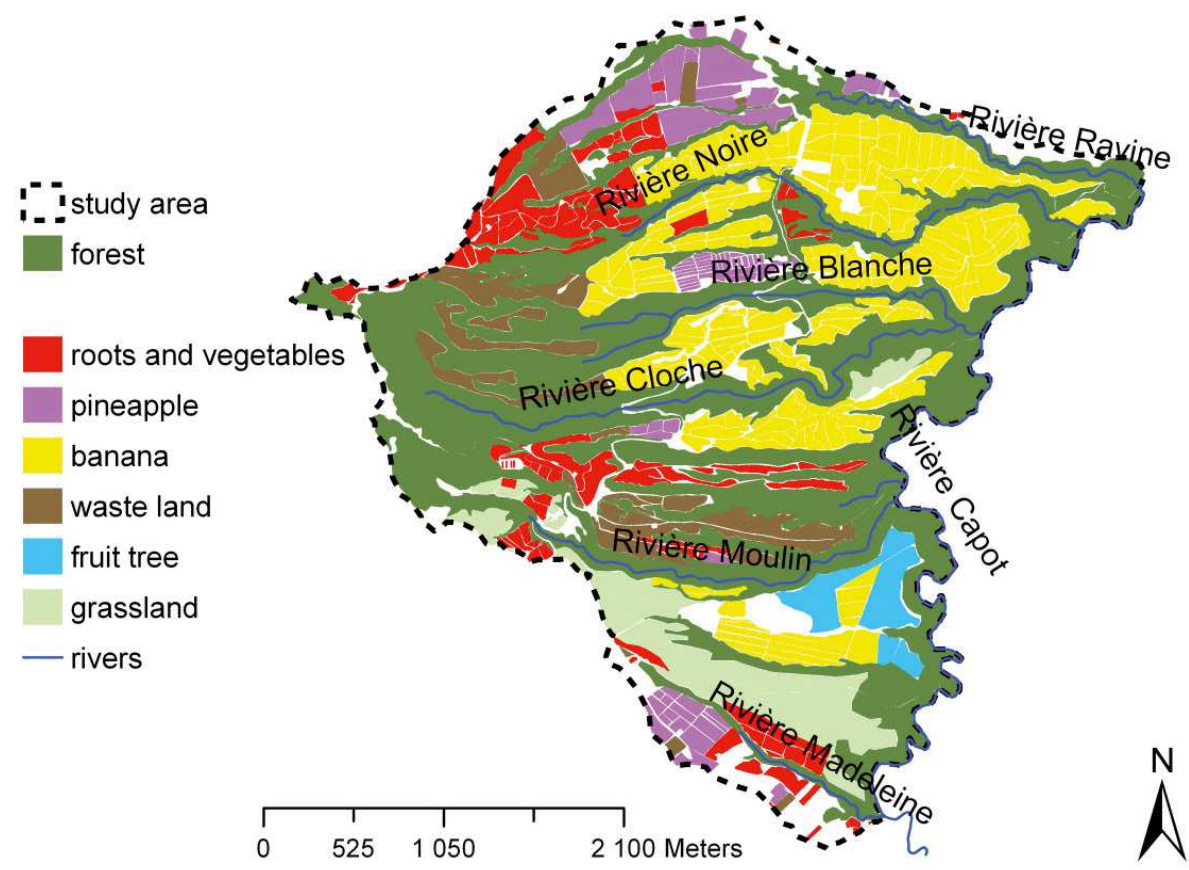

Figure 2. Distribution of land-use types in the watershed of the 'Capot river' and localization of sub-watersheds.

the frequency and the date of application of pesticide during the last 12 months for every field. They also reported the spraying program and the history of the current and previous crops on each field.

During 2001/2002, the pesticide load of the studied area was $46298 \mathrm{~kg}$ of commercial products, corresponding to $19 \mathrm{~kg}$ of active ingredient per hectare treated and $9.6 \mathrm{~kg}$ per ha of agricultural surface. In contrast, in France the mean value is 5.1 to $5.4 \mathrm{~kg}$ of active ingredient per hectare (Aubertot et al., 2005). Among the products applied, 63\% were insecticides, $22 \%$ herbicides and $15 \%$ fungicides. This global load included 18 chemical families and mostly organophosphorus $(2825 \mathrm{~kg})$, phenylpyrazoles $(730 \mathrm{~kg})$, carbamates $(511 \mathrm{~kg})$, triazines $(145 \mathrm{~kg})$ and triazoles $(144 \mathrm{~kg})$.

\subsubsection{Calculation of the field pesticide load (active ingredient load)}

The field active ingredient load is the sum of all the active ingredient loads of a field during the studied period (Girardin et al., 1999). It can be considered as the simplest indicator to evaluate the pesticide risk for the environment and human health. At each time step of the indicator (the year), one calculates $C_{i}$, the load of the active ingredient ' $i$ ' of the field ' $f$ ', by multiplying $D_{i}$, the dose of the active ingredient ' $i$ ' $\left(\mathrm{g} \cdot \mathrm{ha}^{-1}\right)$, by $S_{f}$, the surface of the field where the active ingredient ' $i$ ' is applied (Eq. (1)).

$$
\mathrm{C}_{\mathrm{i}}=\left(\mathrm{D}_{\mathrm{i}} \times \mathrm{S}_{\mathrm{f}}\right)
$$

Then, at each time step of the indicator, one sums the load of all the ' $n$ ' active ingredients to calculate the field load of the field 'f' (Eq. (2)).

$$
\text { Cfield }_{\mathrm{f}}=\sum_{\mathrm{i}=1}^{\mathrm{i}=\mathrm{n}} \mathrm{C}_{\mathrm{i}}
$$

\subsubsection{Calculation of an indicator of pollution contribution (IcPhyto)}

To assess the potential impact of the pesticide program applied to the field ' $\mathrm{f}$ ' and to take into account the choice of the farmer in terms of products and load, we considered the toxicity of each of the active ingredients and their exposure to surface waters (Aubertot et al., 2005). For that, we defined two scores related to their toxicity and solubility before determining the harmfulness factor used to calculate the final indicator, IcPhyto.

\subsubsection{Toxicity score, $\mathrm{Kt}_{i}$}

To assess the toxicity of an active ingredient, we chose to consider the toxicity for mammals because we are dealing with pollution of water for human consumption. For each active ingredient, we considered four classes of lethal dose for $50 \%$ of a male rat population (LD50). The four classes classically used in the international pesticide manual (Tomlin, 1994) lead to a score of $1,2,3$ or 4 for the toxicity score, $\mathrm{Kt}_{\mathrm{i}}$, from an inoffensive to very toxic active ingredient, respectively (Tab. I).

\subsubsection{Exposure score, Kei}

To assess environmental exposure to active ingredients, we chose to consider their solubility because water for humans 
Table I. Relation between the toxicity of active ingredients and the toxicity score, $\mathrm{Kt}_{\mathrm{i}}$

\begin{tabular}{|c|c|c|c|c|}
\hline & \multicolumn{4}{|c|}{ Classes of toxicity $\left(\mathrm{mg} \mathrm{kg}^{-1}\right)$} \\
\hline & & $>1000$ & 100 to 1000 & $<100$ \\
\hline & harmless & slightly toxic & toxic & very toxic \\
\hline Toxicity score $\left(\mathrm{Kt}_{\mathrm{i}}\right)$ & 1 & 2 & 3 & 4 \\
\hline
\end{tabular}

Table II. Relation between the solubility of active ingredients and the solubility score, $\mathrm{Ke}_{\mathrm{i}}$.

\begin{tabular}{|c|c|c|c|c|}
\hline & \multicolumn{4}{|c|}{ Classes of solubility $\left(\mathrm{mg} \mathrm{L}^{-1}\right)$} \\
\hline & & $<1$ & $1-100$ & $100-10000$ \\
\hline & insoluble & slightly soluble & soluble & very soluble \\
\hline Solubility score, $\mathrm{Ke}_{\mathrm{i}}$ (score/4) & 1 & 2 & 3 & 4 \\
\hline
\end{tabular}

Table III. Relation, for each active ingredient, between the harmfulness factor, Fdi, and the harmfulness score, $\mathrm{Kd}_{i} ; 1$ is for no risk and 2.5 for very high risk for the health.

\begin{tabular}{lc}
\hline $\begin{array}{l}\text { Harmfulness factor, } \mathrm{Fd}_{\mathrm{i}} \\
\text { (score/16) }\end{array}$ & $\begin{array}{c}\text { Harmfulness score, } \mathrm{Kd}_{\mathrm{i}} \\
\text { (score/2.5) }\end{array}$ \\
\hline 1 to 4 & 1 \\
5 to 8 & 1.5 \\
9 to 12 & 2 \\
13 to 16 & 2.5 \\
\hline
\end{tabular}

comes mostly from rivers supplied by runoff in Martinique. Furthermore, we assessed the exposure of water to pesticide by using only pesticide properties and not soil and topographic characteristics because (i) the soil type is homogeneous all over the studied area and even in the volcanic ash soils (Nitisol to Andisol), (ii) because runoff is poorly affected by the slope as shown by the runoff equation in Chahinian et al. (2005), and (iii) because we wanted to reduce the number of variables in order to have a rapid tool.

For each active ingredient, we considered four classes of solubility (in mg. $\mathrm{L}^{-1}$ ). The four classes established by Tomlin (1994) lead to a score of $1,2,3$ or 4 for $\mathrm{Ke}_{i}$, from insoluble to very soluble active ingredients (Tab. II).

\subsubsection{Harmfulness factor, $F d_{i}$}

A harmfulness factor, $\mathrm{Fd}_{\mathrm{i}}$, is calculated by multiplying the scores of $\mathrm{Kt}_{\mathrm{i}}$ and $\mathrm{Ke}_{\mathrm{i}}$ (Eq. (3)). For correspondence with toxicity and solubility classification, four classes of $\mathrm{Fd}_{\mathrm{i}}$ and harmfulness score $\mathrm{Kd}_{\mathrm{i}}$ values were defined (Tab. III). This calculation considers that there can be compensation between the toxicity and the solubility scores. The four classes of $\mathrm{Kd}_{\mathrm{i}}$ (1, 1.5, 2 and 2.5) do not start at zero because pollution pressure normally includes variables other than solubility and toxicity. Hence, we assumed that pollution by a given active ingredient cannot be completely nil.

$$
\mathrm{Fd}_{\mathrm{i}}=\mathrm{Kt}_{\mathrm{i}} \times \mathrm{Ke}_{\mathrm{i}}
$$

Table IV. Qualitative classes of the pesticide risk indicator IcPhyto for five classes of scores. The qualitative classes were distributed in order to have five classes of equal range between zero and the maximum observed in our dataset (152010).

\begin{tabular}{lc}
\hline $\begin{array}{l}\text { IcPhyto score } \\
\text { (score/152010) }\end{array}$ & IcPhyto qualitative class \\
\hline 0 & zero \\
0 to 38002.5 & low \\
38002.5 to 76005 & medium \\
76005 to 114007.5 & high \\
$>114007.5$ & very high \\
\hline
\end{tabular}

\subsubsection{Calculation of the indicator of pollution contribution (IcPhyto)}

The pesticide risk indicator IcPhyto is calculated for the field ' $\mathrm{f}$ ' with a surface $\mathrm{S}_{\mathrm{f}}$ and for a pesticide program including ' $n$ ' active ingredients, as presented in equation (4). For an easier representation we transformed IcPhyto into five qualitative classes: zero, low, medium, high and very high (Tab. IV).

$$
\text { IcPhyto }_{\mathrm{f}}=\sum_{\mathrm{i}=1}^{\mathrm{i}=\mathrm{n}}\left(\left(\mathrm{C}_{\mathrm{i}} \times \mathrm{Kd}_{\mathrm{i}}\right) / \mathrm{S}_{\mathrm{f}}\right)
$$

\subsubsection{Construction of a multi-scale and multi-source database}

The last step of our method is the construction of a multiscale and multi-source database for spatial analyses. It includes the spatialization of the pollution risk indicator score for all the fields of the study area by using the GIS program ArcView (version 9.1). Each field was identified using Orthophotoplans (BD Ortho ${ }^{\circledR}$ IGN 2000) and linked with a MSACCESS (version 2003) database. Information concerning the field, the farm, the natural areas and the community is entered, because our aim is to analyze the pollution risk for different landscape elements, keeping the field as the Reference Spatial Object (Wood et al., 1988).

The Spatial Analyst Tools and Spatial Statistics Tools functionalities of the GIS were used to represent the IcPhyto value 
of every field of the study area. A buffer zone area of 50 meters around rivers was established to specifically assess fragile areas where regulations on pesticide applications are stricter, e.g. plane spraying of fungicide is not allowed.

\subsubsection{Evaluation of the pesticide risk indicator}

Because there were only few pesticide measurements in the watershed of the 'Capot' river, we were not able to perform a classical evaluation of the accuracy of model predictions by comparing the predicted score with observed or measured data (Reus et al., 2002). As a consequence, we followed the evaluation method proposed by Bockstaller and Girardin (2003). This evaluation method includes three steps: evaluation of the indicator design, evaluation of the indicator output and evaluation by end-users.

The evaluation of the indicator design allows one to check whether the design of an indicator is based on scientific knowledge and may generate outputs with a good level of accuracy. For this, we compared our indicator with existing ones. This led us to choose a simple and acknowledged aggregation procedure, i.e. the choice of classes for variables to aggregate and the multiplication of the toxicity and the exposure factors. Evaluation of the indicator output was done by experts judging the score calculated by the indicator and by their knowledge. Finally, the evaluation by end-users was done during the first application of the pesticide risk indicator in the landscape evaluation. It was used linked to a social network model (Houdart et al., 2005) to assess the evolution of the pollution risk when the structure of the agricultural landscape changes. The pesticide risk indicator IcPhyto was suitable for this use because the social network model provides only few inputs, yet sufficient to calculate the indicator.

\section{RESULTS AND DISCUSSION}

First, we applied the indicator of pesticide pollution risk IcPhyto to each of the nine sub-watersheds of the Capot River. Figure 3 shows the surface that was assigned to every class of IcPhyto score. The sub-watersheds of 'Ravine', 'Noire' and 'Cloche' have between 10 and 20 hectares of their surface assigned to 'medium' to 'very high' risk class scores; our indicator identifies them as the biggest contributors to the pollution of the whole 'Capot river' watershed. The six other subwatersheds are smaller in surface and are characterized by the score classes 'zero' and 'low'.

Then we analyzed the IcPhyto score in the 50-meter buffer zone next to rivers (Fig. 4). Over the whole 'Capot river' watershed, 33 hectares of the river buffer zone were assigned to 'low', 17 hectares 'medium', and only six hectares 'high' and two hectares 'very high'. The 'Cloche' sub-watershed has most of its river buffer zone in 'medium' and 'high'. This finding confirms that the 'Cloche' sub-watershed is a large polluter of the 'Capot river' watershed. This second analysis confirms the whole sub-watershed analysis (Fig. 3), i.e. the 'Cloche' sub-watershed may constitute a threat to water resources.

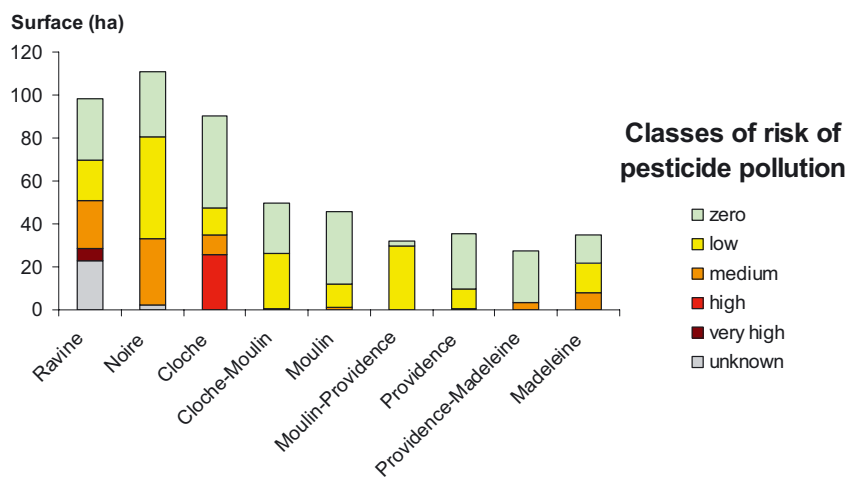

Figure 3. Surfaces for each sub-watershed of the 'Capot river' watershed assigned to score classes of the pesticide pollution risk indicator IcPhyto.

This double analysis at the sub-watershed and in the river buffer zone allowed us to identify the areas in which stakeholders should define a water protection policy. The pesticide pollution risk indicator IcPhyto helps to prioritize the actions of authorities in a complex agricultural watershed.

We chose the 'field' as the Spatial Object of Reference because it is classically considered the best spatial scale to describe agricultural practices (Gras et al., 1989). Indeed, the thinner the Spatial Object of Reference, the more realistic the transfer of information using, for instance, pixellization (Macary et al., 2006; Dumanski et al., 1998; Gibson et al., 2000). The widest temporal scale on which farmers remembered their pesticide actions without notebooks was the year. Acquisition of data concerning pesticide doses spread, and more generally concerning the use of pesticide, is difficult in the case of Martinique because farmers are not always easily accessible and information is not always reliable, and because there is no official database for all the agricultural production. Aubertot et al. (2005) revealed the lack of knowledge about pesticide practices worldwide. This issue is highlighted in the context of Martinique.

Two points were remarkable during the design of the pesticide risk indicator IcPhyto. First, the variables related to toxicity and solubility were chosen in order (i) to fit the specificities of the environment of Martinique, i.e. pesticides are transferred mainly by runoff to a water resource that constitutes only superficial water, and (ii) to account specifically for the pesticide target that the authorities want to evaluate, i.e. the water resource for humans. Second, we set up classes of variables to show differences within the studied area. These specificities provided a barebone indicator for the French West Indies. IcPhyto, however, may be used only in conditions that are similar to those of the French West Indies and when the end-user wants specifically to assess the risk of pollution of the superficial water resource.

The spatialization of IcPhyto allows one to analyze the pesticide pollution risk on different spatial scales, thus accounting for areas with different contributions to pesticide risks. The GIS and the spatialized database allow more refined spatial analysis, including the distribution of load of each pesticide family or of each active ingredient, depending on the 


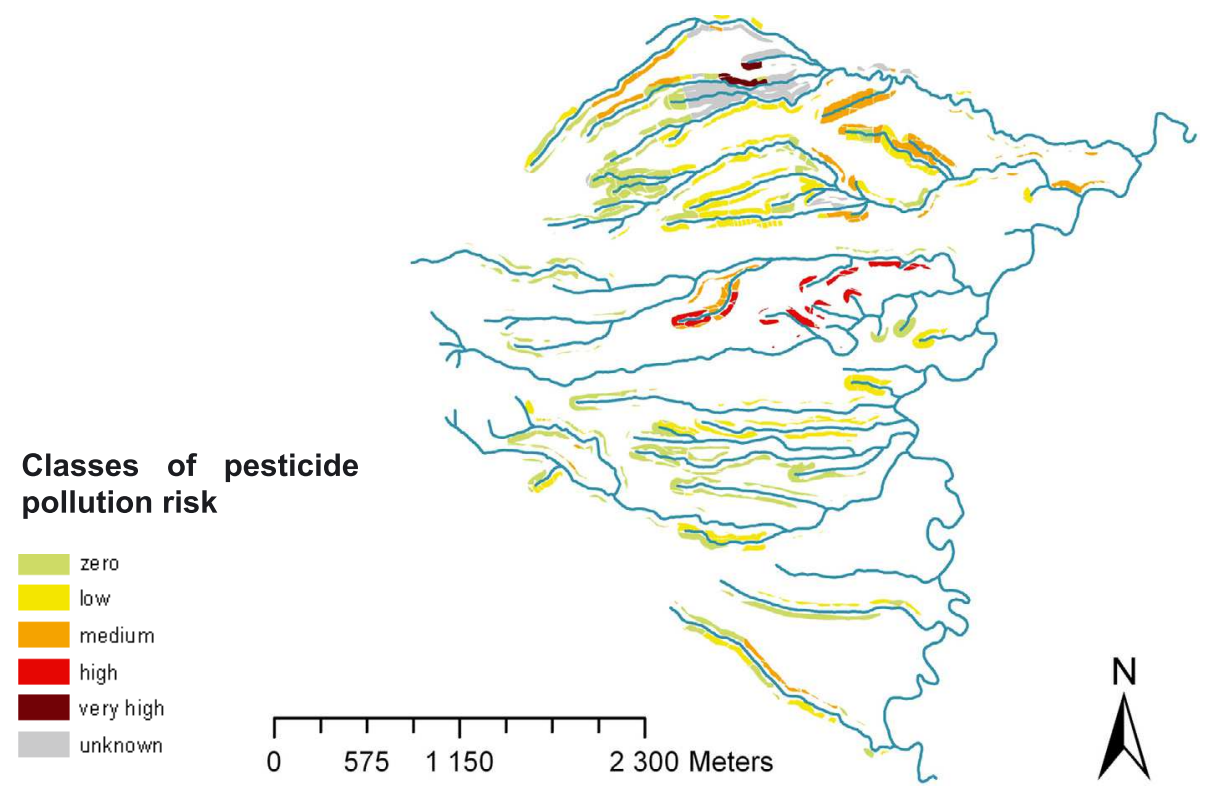

Figure 4. Distribution of IcPhyto qualitative values in the buffer zone of 50 meters next to rivers in the 'Capot river' watershed.

needs of the stakeholders. Spatial analyses are particularly relevant when agri-environmental problems have to be described and explained in a systemic way (Morlon et Benoit, 1990; Gibon et al., 1995; Deffontaines, 1998; Soulard, 1999). IcPhyto makes it easy to manage the pesticide part of agricultural sustainability, by identifying critical areas where the environmental impact could be high and by helping understand agricultural practices on a plot scale.

This indicator is limited by our current knowledge of active ingredient transport and by the fact that outputs are qualitative and not quantitative. Hence, accurate guidelines cannot be drawn up to help stakeholders achieve goals with respect to authorized pesticide concentrations in runoff or drainage water. IcPhyto was designed to compare the risks of different cropping systems, from the field to the watershed, but not to simulate active ingredient concentrations in water. It is a tool dedicated to helping policymakers and authorities locate the areas that contribute most to the pollution of the water resource.

\section{CONCLUSION}

The method presented is particularly useful in Martinique. It can also be used in other areas where it is very difficult to obtain data on both the agricultural practices and the fate of pesticides, and where a specific assessment is required. Indeed, the method provides at once precise knowledge and the global distribution of a phenomenon. It is an open database that can be completed and that permits spatial analysis on different scales and concerning different phenomena. Finally, it both describes and explains the potential risk of water pollution by pesticides by providing qualitative, quantitative and spatial information. Future studies might seek to improve the indicator by integrating more precise data about the soil-climate conditions and about the topography, while maintaining its simplicity.
Acknowledgements: The authors thank the farmers of Martinique for their help in building the pesticide practices database.

\section{REFERENCES}

Aspinall R., Pearson D. (2000) Integrated geographical assessment of environmental condition in water catchments: Linking landscape ecology, environmental modelling and GIS, J. Environ. Manage. 59, 299-319.

Aubertot J.N., Barbier J.M., Carpentier A., Gril J.J., Guichard L., Lucas P., Savary S., Savini I., Voltz M. (2005) Pesticides, agriculture et environnement. Réduire l'utilisation des pesticides et leurs impacts environnementaux. Expertise scientifique collective, synthèse du rapport, INRA et Cemagref, France, 64 p.

Bock M., Rossner G., Wissen M., Remm K., Langanke T., Lang S., Klug H., Blaschke T., Vrscaj B. (2005) Spatial indicators for nature conservation from European to local scale, Ecol. Indic. 5, 322-338.

Bockstaller C. (2004) Élaboration et utilisation des indicateurs. Exemple de I-Phy, in: Barriuso E. (Ed.), Estimation des risques environnementaux des pesticides : un point sur : Paris, INRA Éditions, pp. 75-86.

Bockstaller C., Girardin P. (2003) How to validate environmental indicators, Agr. Syst. 76, 639-653.

Bockstaller C., Girardin P., Van der Werf H.M.G. (1997) Use of agroecological indicators for the evaluation of farming systems, Eur. J. Agron. 7, 261-270.

Bockstaller C., Guichard L., Makowski D., Aveline A., Girardin P., Plantureux S. (2008) Agri-environmental indicators to assess cropping and farming systems. A review, Agron. Sustain. Dev. 28, 139149.

Cattan P., Cabidoche Y.M., Lacas J.G., Voltz M. (2006) Effects of tillage and mulching on runoff under banana (Musa spp.) on a tropical Andosol, Soil Till. Res. 86, 38-51.

Chahinian N., Moussa R., Andrieux P., Voltz M. (2005) Comparison of infiltration models to simulate flood events at the field scale, J. Hydrol. 306, 191-214. 
Colmet-Daage F., Lagache P. (1965) Caractéristiques de quelques groupes de sols dérivés de roches volcaniques aux Antilles françaises, Cahiers de l'ORSTOM série pédologie 8, 91-121.

Corwin D.L., Vaughan P.J., Loague K. (1997) Modeling Nonpoint Source Pollutants in the Vadose Zone with GIS, Environ. Sci. Technol. 31, 2157-2175.

Dalgaard T., Hutchings N.J., Porter J.R. (2003) Agroecology, scaling and interdisciplinarity, Agr. Ecosyst. Environ. 100, 39-51.

Deffontaines J.P. (1998) Les sentiers d'un géo-agronome, Editions Arguments, Paris, 360 p.

Devillers J., Farret R., Girardin P., Rivière J.-L., Soulas G. (2005) Indicateurs pour évaluer les risques liés à l'utilisation des pesticides, Lavoisier, Londres, Paris, New-York, 278 p.

Dumanski J., Pettapiece W.W., McGregor R.J. (1998) Relevance of scale dependent approaches for integrating biophysical and socioeconomic information and development of agroecological indicators, Nutr. Cycl. Agroecosys. 50, 13-22.

FAO (1990) Soil Units of the Soil Map of the World, FAOUNESCOISRIC, Roma, Italy.

Gibson C.C., Ostrom E., Ahn T.K. (2000) The concept of scale and the human dimensions of global change: a survey, Ecol. Econ. 32, 217-239.

Gibon A., Di Pietro F., Theau J.P. (1995) La diversité des structures spatiales des exploitations pyrénéennes, Cahiers Options méditerranéennes, v. 2, 259-266.

Girardin P., Bockstaller C., Van der Werf H.M.G. (1999) Indicators: Tools to evaluate the Environmental Impacts of Farming Systems, J. Sustain. Agr. 13, 5-21.

Gras R., Benoit M., Deffontaines J.P., Duru M., Lafarge M., Langlet A., Osty P.L. (1989) Le fait technique en agronomie. Activité agricole, concepts et méthodes d'étude, INRA/L'Harmattan, Coll. Alternatives rurales, $183 \mathrm{p}$.

Guipponi C. (1998) Environmental evaluation of alternative cropping systems with impact indices of pollution, Eur. J. Agron. 8, 71-82.

Halberg, N., Verschuur G., Goodlass G. (2005) Farm level environmental indicators: are they useful? An overview of green accounting systems for European farms, Agr. Ecosyst. Environ. 105, 195-212.

Houdart M., Bonin M., Le Page C., Fort M., Saudubray F. (2005) SIG, Chorèmes et Systèmes Multi-Agents, Évolution d'un système rural martiniquais et pression polluante, Revue Internationale de Géomatique 15, 339-356.

Lefroy E., Rydberg T. (2003) Emergy evaluation of three cropping systems in southwestern Australia, Ecol. Model. 161, 195-211.

Levitan L., Merwin I., Kovach J. (1995) Assessing the relative environmental impacts of agricultural pesticides: the quest for a holistic method, Agr. Ecosyst. Environ. 55, 153-168.

Macary F., Lavie E., Lucas G., Riglos O. (2006) Méthode de changement d'échelle pour l'estimation du potentiel de contamination des eaux de surface par l'azote, Ingénieries 46, 35-49.
Marceau D.J. (1999) The scale issue in social and natural science, Can. J. Remote Sens. 25, 347-356.

Morlon P., Benoit M. (1990) Étude méthodologique d'un parcellaire d'exploitation agricole en tant que système, Agronomie 6, 499-508.

Panke M., Quimby S. (2000) Pesticides, Caribbean Currents, INFOTERRA/USA, Washington 8, 9 .

Payraudeau S., Van der Werf H.M.G. (2005) Environmental impact assessment for a farming region: a review of methods, Agr. Ecosyst. Environ. 107, 1-19.

Kimura M., Tanaka S., Isoda F., Sekigawa K., Yamakawa T., Sekihara H., Rawlins B.G., Ferguson A.J., Chilton P.J., Arthurton R.S., Rees J.G., Baldock J.W. (1998) Review of Agricultural Pollution in the Caribbean with Particular Emphasis on Small Island Developing States, Mar. Pollut. Bull. 36, 658-668.

Reus J., Leendertse P., Bockstaller C., Fomsgaard I., Gutsche V., Lewis K., Nilsson C., Pussemier L., Trevisan M., Van der Werf H., Alfarroba F., Blümel S., Isart J., McGrath D., Seppälä T. (2002) Comparison and evaluation of eight pesticide environmental risk indicators developed in Europe and recommendations for future use, Agr. Ecosyst. Environ. 90, 177-187.

Sánchez-Bayo F., Baskaran S., Kennedy I.R. (2002) Ecological relative risk (EcoRR): another approach for risk assessment of pesticides in agriculture, Agr. Ecosyst. Environ. 91, 37-57.

Smith C., Mc Donald G. (1998) Assessing the sustainability of agriculture at the planning stage, J. Environ. Manage. 52, 15-37.

Smith O.H., Petersen G.W., Needelman B.A. (2000) Environmental indicators of agroecosystems, Adv. Agron. 69, 75-97.

Soulard C.T. (1999) Les agriculteurs et la pollution des eaux. Proposition d'une géographie des pratiques, Thèse de Doctorat de Géographie, Université Paris I Panthéon-Sorbonne, CNRS LADYSS-INRA SAD, $424 \mathrm{p}$.

Stein A., Riley J., Halberg N. (2001) Issues of scale for environmental indicators, Agr. Ecosyst. Environ. 87, 215-232.

Tixier P., Malezieux E., Dorel M., Bockstaller C., Girardin P. (2007) Rpest - An indicator linked to a crop model to assess the dynamics of the risk of pesticide water pollution application to banana-based cropping systems, Eur. J. Agron. 26, 71-81.

Tomlin C. (1994) The Pesticide Manual Incorporating the Agrochemicals Handbook, 10th edn., British Crop Protection Council, The Royal Society of Chemistry, Farnham, UK.

Van Der Werf H.M.G., Zimmer C. (1998) An indicator of pesticide environmental impact based on a fuzzy expert system, Chemosphere $36,2225-2249$.

Van der Werf H.M.G., Petit J. (2002) Evaluation of the environmental impact of agriculture at the farm level: a comparison and analysis of 12 indicator-based methods, Agr. Ecosyst. Environ. 93, 131-145.

Wood E.F., Sivapalan M., Beven K., Band L. (1988) Effects of spatial variability and scale with implications to hydrologic modeling, J. Hydrol. 102, 29-47. 